\title{
An Empirical Analysis of the Impact of Government Health Expenditures on the Performance of the Health Sector in Nigeria

\author{
Gwaison Panan Danladi ${ }^{1}$ (iD) \\ ${ }^{1}$ Economics and Management Science Department, Nigeria Police Academy, Wudil-Kano, Nigeria
}

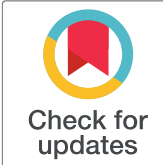

Keywords: Health Capital Expenditures, Health Recurrent

Expenditures, Life Expectancy, Dynamic Ordinary Least Square, COVID-19.

\section{Received Date: \\ 31-07-2021 \\ Accepted Date: \\ 18-09-2021 \\ Publication Date:}

30-09-2021

\begin{abstract}
Purpose of the Study: The purpose of the study is to examine whether government health expenditures have an impact on the health sector performance in Nigeria for the period (19792019).

Methodology: The study employs the expo facto research design. The annual time series data were sourced from World Development Indicators (WDI) and the Statistical Bulletin of the Central Bank of Nigeria $(\mathrm{CBN})$ for several years. The dynamic ordinary least square (DOLS) estimation method is employed to measure the coefficient of the parameters to test the four hypotheses developed.
\end{abstract}

Main Findings: The findings of the study indicate that capital health expenditure and recurrent health expenditures are positively related to the performance of the health sector proxy by life expectancy rate but statistically insignificant. However, capital health expenditure is statistically significant to life expectancy.

Research Implication: It was recommended that priority need to be placed on government capital spending on health such as building and equipping of health centres in every community to enhance accessibility to health centres in Nigeria.

The novelty of the study: There is a need for an adequate mechanism to be put in place by the health sector to check the stealing of public funds and punish those who misuse and divert such funds. This can promote the generation and prudent utilization of revenue to equip our various health centres ahead of eventualities like the COVID-19.
Copyright: (C) 2021. The Authors. Licensee: IJSSER. This work is licensed under the Creative Commons Attribution License 4.0.

Please cite this article as: Danladi, G. P. (2021). An Empirical Analysis of the Impact of Government Health Expenditures on the Performance of the Health Sector in Nigeria. International Journal of Social Sciences and Economic Review, 3(3), 3544.

doi.org/10.36923/ijsser.v3i 3.113

\section{Read online:}

Scan this QR code with your smart phone or mobile device to read online.

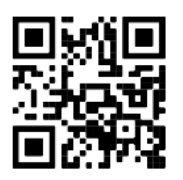

\section{INTRODUCTION}

Globally, the health condition of the people is imperative to a nation's well-being and sustainable economic growth. Health is the general state of the mind and body and not just when there is the absence of sickness, injuries, or disability (Yusuf, 2016). When the health condition of an individual is bad it will be difficult to undertake any economic activity and if they try it there will be no efficiency in productivity hence, health issues should be taken with seriousness (Crémieux, Ouellette, \& Pilon, 1999).

Several studies stated that development in the health sector is a vital requirement for promoting Human Capital Development (HCD) in several and even all economies. Siddiqui, Afridi, Haq, and Tirmazi (1995) stated that increased status of health in a nation leads to outward movement in labour supply curve/rise labour productivity with the effect of a rise in output and investment in human capital. Therefore, public health expenditure level influences human capital development level generally which subsequently resulted in more, better productive, skilful, and efficient investment in other sectors like commerce, education, agriculture, and mining (Ghosh et al., 2007).

In Nigeria, the general government expenditures in the health sector ( recurrent and capital spending) fluctuates. For instance, the capital expenditures fall in 1970 from $\$ 7.3$ million to $\$ 6.88$ million in 1970. However, it increased in 1973 to 16.40 million and further increased to 136.00 in 1983 . It fall drastically to $\$ 1.10$ million in 1984. This situation is since the government was busy with other sectors of the economy hence neglected the capital heal expenditures. It rose in 1990 to 257.00milion. in 1991, the capital expenditure fall to 137.60 million but increased to $188.00 \mathrm{~m}$ in 1992. The statistic increased continuously to $\$ 586.2$, $\$ 17,717.42$ million, $\$ 33,396.97$ million and N34,647.9million in 1993, 2003, 2005 and 2007 respectively. Recently, from2016 to 2017 it rose from $\$ 79.63$ billion to $\$ 147.90$ billion in 2017 (Boachie \& Ramu, 2017; Olakunle et al., 2014).

Similarly, recurrent health expenditure follows the same trend. It increased slowly from $11.90 \mathrm{~m}$ in 1970 to $\$ 14.10 \mathrm{~m}$ in 1971 and to $\$ 109.50 \mathrm{In} 1978$. However, it dropped to but fell to $\$ 72.90 \mathrm{~m}$ in the next year. The trend of recurrent expenditure on health during this time was influenced by government attitude towards health matters and the will of the government to enhance the health system during the oil boom period. Recurrent health expenditure increased sharply from $\$ 87.50 \mathrm{~m}$ in 1979 before it rose to $\$ 155.30 \mathrm{~m}, \mathrm{~N} 167.70 \mathrm{~m} 279.20$ million in 1980,1985 and 1986 respectively.

${ }^{1}$ Corresponding Author: Panan gwaison@yahoo.com 
It increased from $\$ 401.10 \mathrm{~m}$ to $\$ 619.40 \mathrm{~m}$ from 1990 to 1991 , However, the statistic dropped from 1995 to 1996 from $\$ 3,335.70 \mathrm{~m}$ to $\$ 3,192.00 \mathrm{~m}$, then it increased continuously from $\$ 4,860.50$ in 1998 to $\$ 8793.20 \mathrm{~m}$ in 1999 . This statistic increase also in 2005 and 2007 from 44,551.63, to $\$ 72,290$ respectively. Recently, from 2016 to 2017 it rose from 202.36 billion to $\$ 236.10$ billion (Adelowokan Oluwaseyi, 2012).

The healthcare system is imperative to the health production function. This is because a good healthcare system is top among the vital way to lower infant mortality to bring about an enhancement in welfare. In most developing economies such as Nigeria, that child death rate, untidy environment, poverty, inequality, unemployment, communicable diseases, and corruption are high, private individual sector spending on health overshadow. Moreover, in countries that lack health insurance schemes most people pay from their pockets, This tends to reduce the accessibility of health services, particularly in poor areas. The role of health in human capital development and education need not to be overemphasized. In the view of Olopade et al. (2020) contended that the government (expenditures) can play a great part to enhance the accessibility of individuals to health and human capital development. A rise in public expenditure in the health sector not only enhance life expectancy but improved the economy, the long life will lead to expansion in the workforce that will speed growth and development(Anyanwu, Adam, Obi, \& Yelwa, 2015). This study main aim is to examine whether government expenditure on healthcare impacts on health sector performance.

\section{LITERATURE REVIEW}

\subsection{Theoretical Literature}

Generally, many theories were put forward by economists to understand public spendings and the growth of various sectors and on the economy as a whole. Some of these theories that were reviewed are; the law of increasing state activity by Wagner's (1835-1917), Peacock-Wiseman Hypothesis (1891-1955), Baumol's unbalanced productivity growth (1922-2017) theory of public expenditure by Musgrave (1910-2007), and Keynes theory (1883-1946).

\subsubsection{Law of Increasing State Activity by Wagner's (1835-1917)}

Wagner's a great economist start by looking at his country first he looks at other nation in the world. The name of the theory was from one economist who lived in Germany (1835-1917) Adolph Wagner. Wagner propounds the theory by studying the pattern of growth of government expenditures' he also looks at the nature of the public sector in terms of size and further states that:

i. Expansion of the role states play generally resulted in a rise in the public spending in terms of governance or the general control of the entire economy;

ii. Growth in industrialization would lead to rising pressure on the political leadership on the need for social infrastructures with also move for the rise in wages to enhance the conduct of industry;

iii. An expansion in government expenditures can be greater than the proportional rise in the level of countries national income this will result in a relatively wide public sector (Danladi, Sale, \& Elisha, 2019).

\subsubsection{The Peacock and Wiseman's Hypothesis (1891-1955)}

Alan Peacock and Jack Wiseman carried fresh study based on Wagner's theory They examined government spending from 1891 to 1955 in the United Kingdom. They discovered that Wagner's theory still holds.

In addition, They mentioned that:-

1. An increase in government spending largely depends on revenue generation. Over the years, economic growth leads to an increase in governments revenue, this help to expand increase government spending.

2. A large gap exists between the expectations form by citizens on government expenditure and the accepted tax level. Thus, governments cannot run away from the demands made by citizens on various services, in the situation, that the revenue generation is rising at a constant rate.

3. In addition, Peacock and Wiseman mentioned that government raises tax rates, and tax structure to raise additional money for additional defence spending in times of war, by when the war is over, the citizens will be used to the tax rate and tax revenue used in wartime and it will continue as usual. Thus, a rise in government revenue collection lead to rising in public spending (Danladi et al., 2019; Orji, Ogbuabor, Okeke, \& Anthony-Orji, 2018).

\subsubsection{Baumol's Unbalanced Productivity Growth(1922-2017)}

William Jack Baumol was an American great economist. He also made significant contributions to the theory of public expenditure and economic growth theory. According to him, public expenditure may rise due to the rising cost of input in the government sector compared to the private sector. He categorises the economy broadly into two categories.

i. $\quad$ "Progressive Sector" featured with technical development works (such as invention; formation of capital; economic of scale) that lead to increase in the level of output, the total rise in workers' productivity, which explain the resultant rise in justifying salaries of workers;

ii. "Non-progressive Sector": featured with sporadic movement in the level of productivity. Employees are always ending product (such as Teachers, Doctors, Nurses). As a service-oriented sector primarily, with the government sector as the dominant component (health, education, security) Development in Technology is not relevant in this sector as in the other sector (Danladi et al., 2019).

As such differences exist in the sectors, He contended that there cannot be large differences in salaries in the two sectors or every worker would prefer to work with the one with the highest salaries. Public expenditures will rise when the cost of the nonprogressive component rises. This increases costs in the non-progressive sector, lead to a rise in public expenditure. To sustain in this sector compared to other sectors required additional workers in the non-progressive sector. The theory was criticized for 
undermining the chances of technological advancement in the government sector. But, workers' salaries can increase public expenditures (Comfort, Ojamaliya, Okafor, Godwin, \& Oluwapelumi, 2018; Danladi et al., 2019).

\subsubsection{The Theory of Public Expenditure by Musgrave (1910-2007)}

In (1964), Musgrave propounded the theory of public expenditure. He discovers that the need for government services is in three stages of per capita income experience changes in the income elasticity of demand. Musgrave opined that when the per capita income is low the need for government services will be low because the income will be channelled to meet basic needs. In the situation that the per capita income increases above the low level, the demand for public services like security, electricity, health, water, transport and education begin to increase, hence, moving public expenditure on these items to rise. Musgrave notice that, when the per capita income is high, there will befall in the government sector growth rate since most primary needs are provided, in most advanced countries (Danladi et al., 2019).

This theory is quite imperative, however, it has a strong shortcoming, the size of government expenditure cannot be forecasted in later stages. It is not always the case that the share of the government sector further falls during later stages. Because the pattern of private consumption changes because of increasing per capita income in the later industrialization stages, the public share might rises also to satisfied the growing need for government services like health, social security, education, and infrastructure, and. It, therefore, depends on the income level and the individual needs of the citizens if the government share increases or fall.

In addition, it is also always difficult to identify one single level of development for any economy in particular. In underdeveloped countries like Nigeria, different levels can be seen simultaneously: Whereas in towns and cities the economy might be placed in a higher level of development, villages and ghettos are still often far behind and are situated in the lower level of development.

\subsubsection{The Keynesian Theory ( 1883-1946)}

John Maynard Keynes was a British economist in the 1930s in his desire to study the Great Depression. Among several economists who studied public finance and development in the industrial sector output, John Maynard Keynes ( 1883-1946) was one of the popular with his generally different perspective on the issue. He viewed government spending as an exogenous factor that can be used as a policy measure to improve the economy. Keynes believes that public expenditure can result in positive economic growth. Therefore, a rise in public consumption level can result in a rise in investment, profit-making and employment because of its multiplier effects on aggregate or total demand. Since public expenditure support aggregate demand, that stimulates a rise in productivity depending on government spending multipliers. He was so popular for several decades and has great influences on macro-economic policy between the 1930s to the 1980s. The theory has several shortcomings, however, it is still relevant in policy formulation in the public sector (Danladi et al., 2019; Orji et al., 2018).

\subsection{Empirical Literature}

Studies on government expenditure on health and the health sector performance are many, with mixed results while some studies argued that government expenditure does not necessary influences the performance of the health sector, others hold the contrary opinion as reviewed below.

Firstly, Xian et al. (2010) acknowledged that both in the short or long run, government expenditure on health is positively affected by the environmental quality and the country's economy. Assessing the impact of environmental pollution on health care expenditure using panel data in China (31 Chinese provinces) from 1997 to 2003. In estimating the properties of the indicators panel stationarity and panel co-integration were determined. They investigated the short run and the long-run effects of per capita provincial GDP, dust and smug emission, waste and water emissions, and waste and gas emissions on per capita government expenditure on health as the variables.

Secondly, the relationship that exists between expenditures in health care on economic growth in Nigeria in literature. A. a. Bakare and S. Olubokun (2011) employed the ordinary least square method. The findings indicate a significant and positive relationship exists between health care spending and economic growth. It was therefore recommended that the Nigerian government should give more priority to the sector by rises its annual budget allocation. There is a need to transparently utilized the budget in the sector to impact the economy positively.

Also, Ahmed, Naser, and Deam (2016) confirm that health outcomes, public expenditure, income level on government stability, health, and corruption have a long-run relationship. They employed an ARDL to examined the impact of Malaysian public expenditure on health and governance on health outcomes. Their study covered 1984 to2009. However, the results further revealed health outcomes in the short and long run is affected by corruption. The studies recommended a focus on the imperative of health programs and checking the corruption rate in the country.

In addition, Fullman et al. (2018) employed Pearson's moment correlation to examined the impact of public spending on social service in Nigeria (health sector performance) (2000-2013). The study sourced secondary data from CBN statistical bulletins, World Bank, and the Nigerian Budget. Infant mortality rates and life expectancy were proxies for health sector performance correlates against public expenditure. The results show that public expenditure has negatively and statistically significant that is a rise in government allocation in the health sector will result in a fall in children death $\mathrm{t}$ rate. However, a statistically insignificant but weak correlation exists between public spending on health and general life expectancy. Thus, it was suggested that government need to increases allocation in the sector and called for private sector funding of health, this will serve as their corporate and social responsibility in the society to promote growth and development.

However, Onisanwa, Sunday, and Adaji (2018) confirm a contrary result that government spending on health was negatively related to life expectancy and under-five mortality as the governance variable was used. This was a result of the high rate of 
corruption and embezzlement of public health funds in Nigeria. The study employed both OLS and the two-stage least squares to examine the effectiveness of public spending on health and governance in Nigeria. Time series data on government health expenditure, corruption index, Children less than five years death rate and the general life expectancy were proxy for the variable. The study concluded that reducing children death rate and raising general life expectancy in Nigeria will be unachievable if the level of stealing of public funds does not check to the minimal level. These mixed results from the literature necessitate this study.

\section{DATA AND METHODOLOGY}

The study is an empirical study. To determine whether the government expenditures on health have effects on health sector performance in Nigeria. An ex post facto research design was employed. This can be attributed to the fact that the data used in this work cannot be manipulated as tare hey already in existence. This design is systematic empirical research in which researchers does not have direct control of the variables since tare they are already in existence and are not subjected to manipulation by the researcher.

\subsection{Data Sources}

Secondary data in central bank statistical bulletins of 2010, 2013, 2015 and 2016 the world development indicator were used in this study. Time series data used was from 1979-2019. As established from the literature above life expectancy was used as a proxy for the performance of the health Sector and capital, recurrent, and total government health expenditures were the proxy for government expenditures on health used to captured the variables.

\subsection{The Theoretical framework}

To examine whether the government expenditures on health have effects on the performance of the sector in Nigeria. The study employed the work of Grossman (1972) who propounded a theory on the function of health production at the micro-level, which was written as:

$\mathrm{HL}=\mathrm{f}(\mathrm{I})$

From the above equation, HL is an estimate of the health outcomes of an individual I am a vector of the health production function of single individual inputs. Component of the vector is: education, income level, time spends on the healthy procedure, nutrition, general consumption level public goods, genetic makeup, and clean environment. This was established in examining the health production at the micro-level. However, government expenditure on health and performance in the health sector is the focus of this paper at the macro level in Nigeria (Oluwatoyin. 2014 ). To move to macro analysis, using the theory, the component of the vector I were represented by, capital health expenditure and recurrent health expenditure environmental, social, and economic factor vectors as:

$\mathrm{hl}=\mathrm{f}(\mathrm{T}$ C R $)$

where $\mathrm{T}$ is the vector of total government expenditure on health $\mathrm{C}$ means a vector of capital health spending and $\mathrm{R}$ mean vector of recurrent health spending. Equation (ii) in scalar form can be rewritten as:

$h l=f\left(\mathrm{t}_{1}, t_{2 \ldots . . .} t_{n} c_{1}, c_{2} \ldots . \mathrm{c}_{m} r_{1}, \mathrm{r}_{2 \ldots} r_{n}\right)$

From the above equation, hl which is health performance in Nigeria proxy the general life expectancy at birth $\left(\mathrm{t}_{1}, t_{2} \ldots . . t_{n}\right)=t\left(\mathrm{c}_{1}, \mathrm{c}_{2} \ldots \mathrm{c}_{m}\right)=c\left(\mathrm{r}_{1}, \mathrm{r}_{2 \ldots}, r_{n}\right)=r$ in equation( iii) $\mathrm{m}$ and $\mathrm{n}$ are the numbers of variables in each section

\subsection{Model Specifications}

To examine whether the government expenditures on health have no impact on the health sector in Nigeria. The life expectancy (LFEXP) was used as a proxy for health sector performance in Nigeria (dependent variable) while the government capital expenditure on health in Nigeria (CEH), government recurrent expenditure on health in Nigeria( REH) and government total expenditure on health in Nigeria(TGEH) were the proxies for public health expenditures the independent's variables. The above theoretical framework was used in the below specification of government expenditure on health and the performance of the health sector equation as:

LFEXP $=$ f (GHEXP) ...........................

The government health expenditures in Nigeria can be categorized into capital expenditure on health, recurrent expenditure on health and total expenditure on health (CEH, REH, TGEH). Thus

LFEXP $=\mathrm{f}(\mathrm{CEH}, \mathrm{REH}, \mathrm{TGEH}) \ldots \ldots \ldots \ldots \ldots \ldots \ldots \ldots \ldots . . .2$

This can be expanded as;

$L F E X P_{t}=\beta_{0}+\beta_{1} C E H_{t}+\beta_{2} R_{E H}+\beta_{3} T G E H_{t}+\mu_{t} \ldots \cdots \cdots \cdots \cdots \cdots \cdots \cdots \cdots \cdots \cdots \cdots \cdots \cdots \cdots$

Where;

LFEXP $=$ represent the general life expectancy at birth in Nigeria;

$\mathrm{f}=$ function;

$\mathrm{CEH}=$ government capital expenditure on health in Nigeria;

$\mathrm{REH}=$ government recurrent expenditure on health in Nigeria;

TGEH $=$ total expenditure on health in Nigeria;

$\beta 0=$ the intercept of the function;

$\beta 1, \beta 2, \& \beta 3=$ represents the slope coefficients of the function; 
$\mu \mathrm{t}=$ the stochastic variable, disturbance term or error term.

Aporiri Expectations: $\beta 1>0 \beta 2>0 \beta 3>0$

\subsection{Estimation Procedure}

This paper used descriptive and analytical techniques of data analysis. Mean, standard deviation, Skewness, Kurtosis and JarqueBera were employed among the descriptive tools to establish the normality of the data. In the analytical or inferential tool, DOLS regression techniques were utilized because of their good qualities of best, linear, unbiasedness and efficiency. This estimation involves three stages, pre estimation stage such as descriptive statistics, unit root test, cointegration test, and the Error correction model test (ECM). The estimation stage is the OLS estimation to measure the various parameters in the model. The postestimation stage such as serial correlation LM test, normality distribution test, heteroscedasticity test, and Cusum parameter stability test. These estimations were carryout with the aids of e-view 10 software.

\section{EMPIRICAL ANALYSIS}

\subsection{The Descriptive Evidence}

LFEXP, TGEH, CEH, and REH were subjected to descriptive statistics and the results were revealed in Table 1. LFEXP, TGEH, $\mathrm{CEH}$, and REH mean were not the same. This indicated that LFEXP, TGEH, CEH, and REH reveal significant changes in magnitude, suggesting that some biases in the results will occur when the measurement of the variables is in levels. The JarqueBera statistics p-value of all the variable were less than 0.05. The null of the Jarque-Bera test is that the variables are not normally distributed. So statistical significance of the p-value indicates a rejection of the null hypothesis. All the variables used are normally distributed Therefore the time series data in each variable used in this study are normally distributed.

TABLE 1

Descriptive Statistics of LFEXP, TGEH, CEH, and REH.

\begin{tabular}{l|c|c|c|c}
\hline \multicolumn{1}{c|}{ Descriptive Statistics } & LFEXP & TGEH & CEH & REH \\
\hline Mean & 46.87333 & 54456.92 & 11492.28 & 26978.01 \\
\hline Median & 45.84668 & 16180.40 & 2012.800 & 4860.500 \\
\hline Maximum & 50.94941 & 447948.2 & 46649.80 & 102620.0 \\
\hline Minimum & 45.11571 & 236.4000 & 69.50000 & 133.9000 \\
\hline Std. Dev. & 1.864569 & 101138.9 & 16099.29 & 35086.28 \\
\hline Skewness & 0.917215 & 2.845640 & 1.137942 & 1.066012 \\
\hline Kurtosis & 2.439416 & 10.83857 & 2.624548 & 2.647760 \\
\hline Jarque-Bera & 3.832699 & 97.74368 & 5.542302 & 4.864168 \\
\hline Probability & 0.042143 & 0.000000 & 0.022590 & 0.037854 \\
\hline Sum & 1171.833 & 1361423. & 287307.0 & 674450.2 \\
\hline Sum Sq. Dev. & 83.43886 & $2.45 \mathrm{E}+11$ & $6.22 \mathrm{E}+09$ & $2.95 \mathrm{E}+10$ \\
\hline Observations & 41 & 41 & 41 & 41 \\
\hline Sours & & & \\
\hline
\end{tabular}

Source: Authors Computation, 2021 (Eview-10.0)

\subsection{Correlation matrix}

Table 2 shows the correlation matrix which shows the relationship between the dependent and the independent variables among the independent variable themselves.

TABLE 2

Correlation matrix

\begin{tabular}{l|c|c|c|c}
\hline & LFEXP & TGEH & CEH & REH \\
\hline LFEXP & 1.000000 & 0.629821 & 0.781448 & 0.713878 \\
\hline TGEH & 0.629821 & 1.000000 & 0.600354 & 0.542484 \\
\hline CEH & 0.781448 & 0.600354 & 1.000000 & 0.728568 \\
\hline REH & 0.713878 & 0.542484 & 0.728568 & 1.000000 \\
\hline
\end{tabular}

Source: Authors Computation, 2021 (Eview-10.0)

Table 2 presents the correlation coefficient results which reveals, there are no high correlations of up to 0.8 or more among the variables of the study. Since none of the coefficients is more than 0.8 , thus there is the absence of harmful multicollinearity.

\subsection{The Unit Root Test}

In economics, macroeconomic time series data mostly exhibit a stochastic trend feature, this trend can be check by differencing. The unit root test is used to establish the stationarity or otherwise of each variable in the model. This help to reduce the issue of spurious regression result at the end. In carrying out this test we add the lagged values to the dependent variable the error term is serially uncorrelated (Danladi et al., 2019).

There are many tests developed that can be used to estimate the unit test, however, the Augmented Dickey-Fuller (ADF) and Phillips-Perron (PP) tests were employed in this paper to establish the stationarity or otherwise of each variable. The summary result were presented in table 2 below.

\section{TABLE 3}




\begin{tabular}{lccc}
\hline Variables & ADF Test Statistic(at first difference) & Order of Integration & P-Value \\
\hline LFEXP & $-4.767329(-2.981038)^{*}$ & $I(1)$ & 0.0008 \\
\hline$T G E H$ & $-7.085995(-2.951125)^{*}$ & $I(1)$ & 0.0000 \\
\hline$C E H$ & $-6.776570(-3.622033)^{*}$ & $I(1)$ & 0.0001 \\
\hline$R E H$ & $-4.168742(-3.655446)^{*}$ & $I(1)$ & 0.0190 \\
\hline
\end{tabular}

Source: Authors Computation using E-view-10.0 software (2021)

TABLE 4

PP Unit Root Test Results

\begin{tabular}{lccc}
\hline Variables & PP Test Statistic(at first difference) & Order of Integration & P-Value \\
\hline$L F E X P$ & $-2.847417(-1.951332)^{*}$ & $I(1)$ & 0.0058 \\
\hline$T G E H$ & $-11.38220(-3.544284)^{*}$ & $I(1)$ & 0.0000 \\
\hline$C E H$ & $-6.706719(-3.622033)^{*}$ & $I(1)$ & 0.0001 \\
\hline$R E H$ & $-9.639448(-3.62203)^{*}$ & $I(1)$ & 0.0000 \\
\hline
\end{tabular}

Source: Authors Computation usingE-view-10.0 software (2021)

The summary of the unit test results from tables 3 and 4 above, found out that LFEXP, TGEH, CEH and REH were not stationary at level 1(0). However, at first difference 1(1) that is at 5\%, all the variables were stationary. This result gives insight for more analysis.

\subsection{Co-integration test}

In econometrics, cointegration tests are used to test whether a long-run relationship exists among CEH, REH, TGEH and LFEXP variables in the model above. Working with two or more variables there is a situation that the emerging cointegrating vectors governing the joint evolution of all the series will be more than one. Engle-Granger approach was adopted in this study because it is suitable for a single equation as in the model above (Asteriou \& Hall, 2006).

Table 5

Engle-Granger Cointegration test

\begin{tabular}{|c|c|c|c|c|}
\hline Dependent & tau-statistic & Prob.* & z-statistic & Prob.* \\
\hline LFEXP & -1.835379 & 0.9101 & -47.86603 & 0.0000 \\
\hline TGEH & -6.089683 & 0.0033 & -86.23938 & 0.0000 \\
\hline CEH & -3.352586 & 0.3153 & -16.57316 & 0.2482 \\
\hline REH & -4.264781 & 0.0880 & -48.82124 & 0.0000 \\
\hline
\end{tabular}

Source: Authors Computation, 2021 (Eview-10.0)

The tau-test statistics in table 5 shows one cointegrating equation at $5 \%$. This means that a long-run relationship exists in the variable.

TABLE 6

The Short-run ECM Test

\begin{tabular}{|c|c|c|c|c|}
\hline Variable & Coefficient & Std. Error & t-Statistic & Prob. \\
\hline CointEq(-1)* & -0.710904 & 0.086005 & -2.452242 & 0.0235 \\
\hline R-squared & 0.88629 & \multicolumn{2}{|c|}{ Mean dependent var } & 0.082559 \\
\hline Adjusted R-squared & 0.88629 & \multicolumn{2}{|c|}{ S.D. dependent var } & 0.695694 \\
\hline S.E. of regression & 0.626654 & \multicolumn{2}{|c|}{ Akaike info criterion } & 1.942334 \\
\hline Sum squared resid & 9.424686 & \multicolumn{2}{|c|}{ Schwarz criterion } & 1.991089 \\
\hline Log-likelihood & -23.27917 & \multicolumn{2}{|c|}{ Hannan-Quinn criter. } & 1.955856 \\
\hline Durbin-Watson stat & 1.784513 & & & \\
\hline
\end{tabular}

Source: Authors Computation, 2021 (Eview-10.0)

The ECM result -0.710904 was negative, less than one and significant which meet all the necessary conditions with high speed of adjustment in times of shocks. LFEXP a proxy for health sector performance is indeed cointegrated, and the statistical significance on its long-run growth path, effectively adjusts to short-run shocks by about 71.09 percent in each period.

\subsection{Model Estimation}

The parameter of the intercept and the coefficient of CEH, REH, and TGEH were estimated below using DOLS since all the variables were stationary at first difference 1(1).

From our model establish above,

LFEXP $_{t}=\beta_{0}+\beta_{1} C E H_{t}+\beta_{2} R E H_{t}+\beta_{3} T G E H_{t}+\mu_{t} \ldots \ldots \ldots \ldots \ldots \ldots \ldots \ldots \ldots . .3$

TABLE 7

Model Estimation 


\begin{tabular}{l|l|l|l|l|}
\hline Variable & Coefficient & Std. Error & t-Statistic & Prob. \\
\hline TGEH & $9.55 \mathrm{E}-06$ & $8.54 \mathrm{E}-06$ & 1.118238 & 0.2924 \\
\hline REH & $8.38 \mathrm{E}-05$ & $3.34 \mathrm{E}-05$ & 1.505553 & 0.4172 \\
\hline CEH & 0.53530 & 3.200118 & 2.850219 & 0.03360 \\
\hline C & 45.36429 & 0.164814 & 275.2454 & 0.0000 \\
\hline R-squared & 0.989250 & Mean dependent var & 46.91505 \\
\hline Adjusted R-squared & 0.974916 & S.D. dependent var & 1.953952 \\
\hline S.E. of regression & 0.309464 & Sum squared resid & & 0.861910 \\
\hline Long-run variance & 0.210011 & & \\
\hline
\end{tabular}

Source: Authors' Computation usingE-view-10.0 software (2021)

LFEXP $_{t}=45.36+0.5 \mathrm{CEH}_{t}+8.4 \mathrm{REH}_{t}+9.5 \mathrm{TGEH}_{t}+\mu_{t} \ldots \ldots \ldots \ldots \ldots \ldots \ldots \ldots \ldots . .4$

$\mathrm{SEE}=(0.16)(3.2)(3.3)(8.5)$

$\mathrm{t}^{*}=\quad 275.242 .82 .51 .1$

$R^{2}=0.9892 \overline{R^{2}}=0.9749$

\subsection{Statistical Test of Hypothesis}

The four hypotheses from the objectives of the studies above were tested.

H0: Government health expenditures do not have a significant impact on the performance of the health sector.

In table 7 above, the p-value of TGEH (0.2924) is more than 0.05 . Thus, we retained the $\mathrm{H}_{1}$ and conclude that government expenditures on health do not have a significant impact on the performance of the sector.

$\mathbf{H O}_{2}$ : Government recurrent expenditures on health do not have a significant impact on the performance of the health sector.

In table 7 the p-value of REH (0.4172) is more than 0.05 . Thus we retained the $\mathrm{H}_{2}$ and conclude that government recurrent expenditures on health do not have a significant impact on the performance of the health sector in Nigeria.

Using $\mathbf{H 0}_{3}$ : Government capital expenditures on health do not have a significant impact on the performance of the health sector. In table 7 the p-value of CEH (0.03360) is less than 0.05 . Thus we reject the $\mathrm{HO}_{3}$ and concluded that government capital expenditures on health have a significant impact on the performance of the health sector in Nigeria.

H0$_{3}$ : Government expenditures on health have no causal link with the performance of the health sector in Nigeria.

TABLE 8

The Granger Causality Tests

\begin{tabular}{|c|c|c|c|}
\hline Null Hypothesis & Obs & F-Statistic & Prob. \\
\hline TGEH does not Granger Cause LFEXP & 41 & 0.76885 & 0.4731 \\
\hline \multicolumn{2}{|l|}{ LFEXP does not Granger Cause TGEH } & 3.31180 & 0.0412 \\
\hline REH does not Granger Cause LFEXP & 41 & 3.68432 & 0.0456 \\
\hline \multicolumn{2}{|l|}{ LFEXP does not Granger Cause REH } & 6.09001 & 0.0095 \\
\hline CEH does not Granger Cause LFEXP & 41 & 0.06399 & 0.9382 \\
\hline \multicolumn{2}{|l|}{ LFEXP does not Granger Cause CEH } & 4.48632 & 0.0263 \\
\hline REH does not Granger Cause TGEH & 41 & 1.37660 & 0.2778 \\
\hline \multicolumn{2}{|l|}{ TGEH does not Granger Cause REH } & 2.62133 & 0.1002 \\
\hline CEH does not Granger Cause TGEH & 41 & 1.73574 & 0.2045 \\
\hline \multicolumn{2}{|l|}{ TGEH does not Granger Cause CEH } & 3.40804 & 0.03409 \\
\hline CEH does not Granger Cause REH & 41 & 1.15629 & 0.1328 \\
\hline \multicolumn{2}{|l|}{ REH does not Granger Cause CEH } & 5.04341 & 0.0182 \\
\hline
\end{tabular}

Source: Authors Computation, 2021 (Eview-10.0)

The Causality Tests in table 8 indicated a unidirectional causality. LFEXP lead to variation in TGEH, however, TGEH does not lead to variation in LFEXP. Also, there is unidirectional causality between CEH and LFEXP. LFEXP lead to a change in CEH, however, CEH does not lead to change in LFEXP. LFEXP lead to a change in REH, however, REH does lead to change in LFEXP.

4.7. Post-EstimationDiagnostics Tests

i) Test for Serial correlation

TABLE 9

Serial Correlation LM Test Breusch-Godfrey 


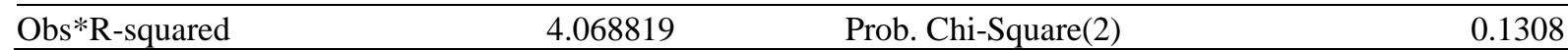

Source: Authors Computation usingE-view-10.0 software (2021)

The Breusch-Godfery LM test in table 7 the p-value $0.1308>0.05$ therefore we retained the hypothesis that serial correlation does not exist among the variables.

ii) Heteroskedasticity Test

TABLE 10

Breusch-Pagan-Godfrey Heteroskedasticity Test

\begin{tabular}{l|l|l|l}
\multicolumn{1}{c|}{ F-statistic } & \multicolumn{10}{c|}{$\mathbf{1 0 . 1 6 8 5 3}$} & \multicolumn{1}{c}{ Prob. F(3,34) } & \multicolumn{1}{c}{$\mathbf{0 . 1 3 4 1}$} \\
\hline Obs*R-squared & 17.97073 & Prob. Chi-Square(3) & 0.0004 \\
\hline Scaled explained SS & 27.79424 & Prob. Chi-Square(3) & 0.5346 \\
\hline
\end{tabular}

Source: Authors' Computation using E-view-10.0 software (2021)

Since the p-value in table 8 was $0.1341>0.05$. Therefore we retained the $\mathrm{H} 0$ and conclude that heteroscedasticity does not exist between the variables at 0.05 or the result is homoscedastic.

\section{iii) Normal Distribution Test}

To establish the assumption of normality in OLS, the normal distribution test was employed below in figure 1. Jarque-Bera statistics and the histogram helps to establish that.

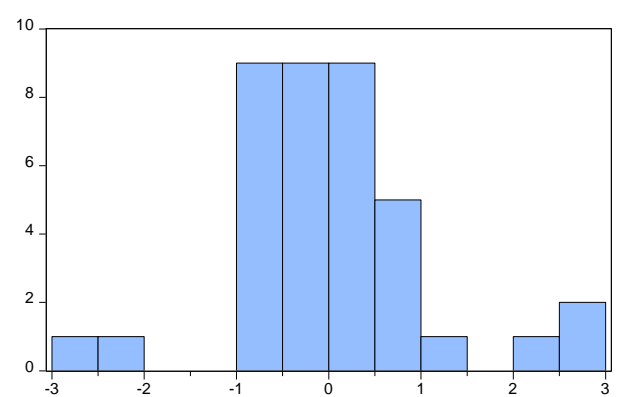

Figure 1: Normality test

Source: Authors Computation, 2021 (Eview-10.0)

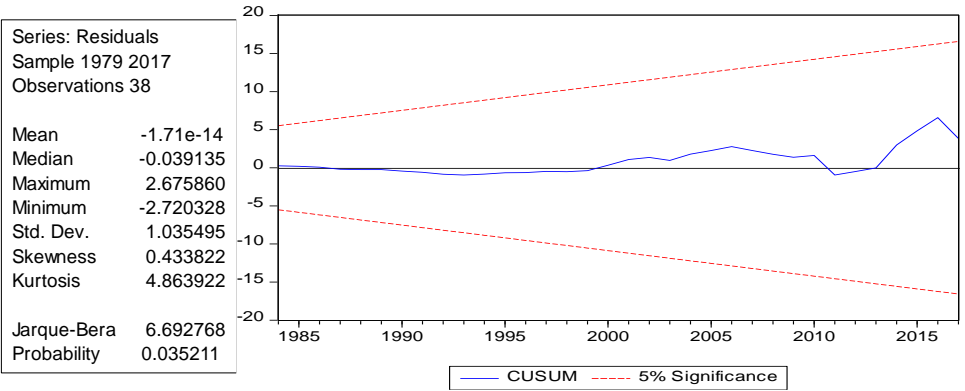

Figure 2: CUSUM test

Source: Authors Computation, 2021 (Eview-10.0)

The shape histogram above indicated that the residuals were normally distributed. Also, the Jarque-Bera statistics further show normal distribution since the $\mathrm{p}$-value $(0.035211)<0.05$.

\section{iv) Parameter Instability Test- CUSUM test}

The parameter instability test is one among the post- estimation test used to show the parameter instability in a situation that the total sum moves outside the borders between the two red lines (critical line) in the graph. The CUSUM test is used to establish it.No specification is needed it is only to construct the total sum of the recursive residuals together with the critical line at $5 \%$ to establish it.

The CUSUM test results in figure 2 above, shows that there is parameter stability from the curve since the total sum did not move outside the border between the two red lines (critical line) at $5 \%$.

\section{DISCUSSION}

The first results revealed a positive but insignificant impact exists between Government expenditures and health sector performance in Nigeria. A unit rise in Government expenditures on the health sector will lead to an increase in the performance of the health sector proxy by life expectancy by 1.8 units and vice versa. This finding agreed with the works of Omosuyi, Ojo, and Olorunfemi (2008); A. a. Bakare and S. Olubokun (2011); and A. S. Bakare and S. Olubokun (2011) their findings show that public expenditure has negatively but significant to a children death rate that is a rise in government allocation in the health sector can cause a fall in children death rate also a positive but statistically insignificant impact between public health spending and the performance in the health sector, that is the general life expectancy. With some level of an increase in public expenditures in the health sectors in the past decades, the health sector in Nigeria is yet to meet up with international standards in terms of health infrastructures and personnel compared to other advanced countries. The rottenness in our health sector need not be overemphasized. The recent COVID-19 pandemic has revealed it. In 2000, Nigerian was number187 out of 191 countries

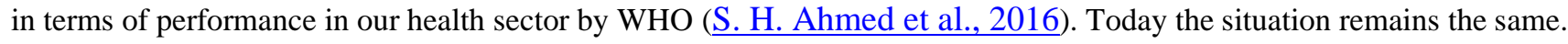

Secondly, the finding shows no significant impact between Government recurrent expenditures on health and the performance of the health sector in Nigeria. However, a positive relationship exists between Government recurrent health expenditures and the performance of the health sector in Nigeria. A unit rise in government recurrent health expenditures will increase the performance of the health sector proxy by life expectancy units.30 units and vice versa. This finding agreed with the works of Omosuyi et al. (2008) and Bakare and Olubokun (2011) and show an insignificant relationship exists between public spending and general life expectancy. They further stated that poor budget implementation is the main cause of poor effective government expenditures in Nigeria and several developing economies. The Bank (2018) and Organization (2010) used some health indicators to compared countries and Nigeria was number 74 among 115 countries with all the public health expenditures 
invested in the sector. Organization (2005) stated that Nigeria is among the countries with the high rate of infant mortality, 91 children died between the ages of 0-5years out of 1000 birth. Today, the story has not changed.

Thirdly, the findings further revealed that Government capital health expenditures have a significant relationship with the performance of the health sector. A positive relationship exists between government capital expenditures in the health sector and the performance of the sector. A unit rise in Government capital health expenditures will increase the performance of the health sector proxy by life expectancy by 7 unitsunit and vice versa. This finding agreed with the works of Xian et al. (2010); Ebiringa and Charles-Anyaogu (2012); and Barenberg, Basu, and Soylu (2015) that also indicated that government expenditure on the health sector decreases the children death rate. A unit rise in government expenditures in the health sector resulted in a unit fall in the $\mathrm{n}$ infant mortality rate. This also implies an increase in life expectancy. Finally, the causality test findings indicate a unidirectional causality. That is LFEXP led to change in TGEH, however, TGEH does not let to change in LFEXP.

\section{CONCLUSION}

Efficiency in allocation and utilization of scarce resources in various competitive sectors is the major challenge facing governments in underdeveloped countries like Nigeria. adequate allocation of funds and infrastructures in the sector led to a significant performance in the sector. This paper examined whether the government expenditures on health have an impact on the performance of the health sector in Nigeria. Literature was review, secondary data were obtained, analyses and findings were made.

Obviously, investment in the health sector leads to economic growth since health is wealth. Several funds were allocated to our health sectors every year but our health centres were not up to international standards to provide quality health needs of Nigerians. The recent COVID-19 pandemic has revealed the level of poor investment in the Nigerian health sector. This has resulted in poor performance in the sector and over-reliance on foreign countries for support. In the 2021 budget proposal, the Nigerian government has increased its budgetary allocation in the sector. However, it is still below $15 \%$ of the total yearly budget recommended by WHO. By and large, government spending on the health sector is imperative to health sector performance and economic growth. It helps to increase life expectancy from birth and productivity of labour in any country

\section{POLICY RECOMMENDATION}

In line with the results and conclusion made above, the following policy recommendations were made;

1. In line with the recommendation of WHO, $15 \%$ of the Nigerian yearly budget should be allocated to the sector. The health sector should also be accountable and transparent. Since capital health expenditure had a positive and significant impact on health performance in Nigeria in the study

2. More priority needs to be placed on government capital spending on health such as building and equipping health centres in every community to enhance accessibility to health centres in Nigeria. Since this will promote growth in the sector and the economy generally

3. Nigeria's health policy like malaria eradication, polio eradication, HIV/AIDS, tuberculosis prevention and national health insurance scheme (NHIS), should be properly implemented, monitored and evaluated to enhance the health status of more citizens in Nigeria. Since this will enhance life expectancy in Nigeria. The private health sectors should also key into this program and policies

4. The international health organization such as WHO and other NGOs should organize more training and retraining for Nigerian health workers to attained international standards in terms of skills. This will enhance health services quality in Nigeria and life expectancy

5. There is a need for an adequate mechanism to be put in place by the health sector to check the stealing of public funds and punish those who misuse and divert such funds. This can promote the generation and prudent utilization of revenue to equip our various health centres ahead of eventualities like the COVID-19 pandemic. Since corruption has hindered the impact of health expenditure on health sector performance in Nigeria.

\section{REFERENCES}

Adelowokan Oluwaseyi, A. (2012). Growth effect of education and health expenditure in Nigeria Nigeria: critical issues and strategies for enhancing the use by the rural communities. Journal of Public Health and Epidemiology, 4(1), 5-13. doi:DOI: 10.5897/JPHE11.133

Ahmed, D. H., Naser, J., \& Deam, R. T. (2016). Particles impact characteristics on cutting surface during the abrasive water jet machining: Numerical study. Journal of materials processing technology, 232, 116-130.

Ahmed, S. H., Bouk, S. H., Yaqub, M. A., Kim, D., Song, H., \& Lloret, J. (2016). CODIE: Controlled data and interest evaluation in vehicular named data networks. IEEE Transactions on Vehicular Technology, 65(6), 3954-3963.

Anyanwu, S. O., Adam, J., Obi, B., \& Yelwa, M. (2015). Human capital development and economic growth in Nigeria. Journal of Economics and Sustainable Development, 6(14), 16-26.

Asteriou, D., \& Hall, S. (2006). Applied econometrics (ISBN: 978-0-230-27182-1). In: Palgrave Macmillan.

Bakare, \& Olubokun. (2011). Health care expenditure and economic growth in Nigeria: An empirical study. Journal of Emerging Trends in Economics and Management Sciences, 2(2), 83-87.

Bakare, A. a., \& Olubokun, S. (2011). Health care expenditure and economic growth in Nigeria: An empirical study. Journal of Emerging Trends in Economics and Management Sciences, 2(2), 83-87. 
Bakare, A. S., \& Olubokun, S. (2011). The exchange rate determination in Nigeria: The purchasing power parity option. Mathematical Theory and Modeling, 1(2), 5-22.

Bank, W. (2018). Poverty and shared prosperity 2018: Piecing together the poverty puzzle. In: The World Bank.

Barenberg, A. J., Basu, D., \& Soylu, C. (2015). The effect of public health expenditure on infant mortality: Evidence from a panel of Indian States, 1983-84 to 2011-12. Retrieved from

Boachie, M. K., \& Ramu, K. (2017). Public Health Expenditure and Health Outcomes: A Review. International Journal of Management and Development Studies, 6(1), 15-21.

Comfort, E., Ojamaliya, A., Okafor, V., Godwin, A., \& Oluwapelumi, A. (2018). Dynamic impact of energy consumption on the growth of Nigeria economy (1986-2016): Evidence from symmetrical autoregressive distributed lag model. International Journal of Energy Economics and Policy, 8(2), 188-195.

Crémieux, P. Y., Ouellette, P., \& Pilon, C. (1999). Health care spending as determinants of health outcomes. Health economics, 8(7), 627-639.

Danladi, G. P., Sale, Z., \& Elisha, G. A. (2019). Effects of government expenditure on manufacturing sector in Nigeria (1986-2016). Dutse journal of economic development, 7(1), 70-81.

Ebiringa, O. T., \& Charles-Anyaogu, N. (2012). Impact of government sectorial expenditure on the economic growth of Nigeria. International Journal of Economic Research, 3(6), 82-92.

Fullman, N., Yearwood, J., Abay, S. M., Abbafati, C., Abd-Allah, F., Abdela, J., . . Aboyans, V. (2018). Measuring performance on the Healthcare Access and Quality Index for 195 countries and territories and selected subnational locations: a systematic analysis from the Global Burden of Disease Study 2016. The Lancet, 391(10136), 2236-2271.

Ghosh, S., Bansal, G. C., Gupta, S. C., Ray, D., Khan, M. Q., Irshad, H., . . Ahmed, J. S. (2007). Status of tick distribution in Bangladesh, India and Pakistan. Parasitology research, 101(2), 207-216.

Olakunle, O. S., Oladimeji, O., Olalekan, A. W., Olugbenga-Bello, A., Akinleye, C., \& Oluwatoyin, O. A. (2014). Knowledge of tuberculosis management using directly observed treatment short course therapy among final year medical students in South Western Nigeria. Pan African Medical Journal, 18(1).

Olopade, B. C., Okodua, H., Oladosun, M., Matthew, O., Urhie, E., Osabohien, R., . . . Johnson, O. H. (2020). Economic growth, energy consumption and human capital formation: Implication for knowledge-based economy. International Journal of Energy Economics and Policy, 10(1), 37-43.

Omosuyi, G., Ojo, J., \& Olorunfemi, M. (2008). Geoelectric sounding to delineate shallow aquifers in the coastal plain sands of Okitipupa Area, Southwestern Nigeria. The Pacific Journal of Science and Technology, 9(2), 562-577.

Onisanwa, I. D., Sunday, B. S.-I., \& Adaji, M. O. (2018). Healthcare financing and health status analysis in Nigeria. Amity Journal of Healthcare Management, 3(2), 31-42.

Organization, W. H. (2005). World health development indicators. Washington, DC.

Organization, W. H. (2010). The world health report: health systems financing: the path to universal coverage: executive summary. Retrieved from

Orji, A., Ogbuabor, J. E., Okeke, C., \& Anthony-Orji, O. I. (2018). Another side of the coin: Exchange rate movements and the manufacturing sector in Nigeria. Journal of Infrastructure Development, 10(1-2), 6379.

Siddiqui, R., Afridi, U., Haq, R., \& Tirmazi, S. H. (1995). Determinants of Expenditure on Health in Pakistan [with Comments]. The Pakistan development review, 34(4), 959-970.

Xian, J., Zhang, Z., Wang, Z., Li, J., Yang, B., Man, F., . . . Zhang, Y. (2010). Value of MR imaging in the differentiation of benign and malignant orbital tumors in adults. European radiology, 20(7), 1692-1702.

Yusuf, M. B. (2016). An assessment of the impact of government expenditure on infrastructures: evidence from Nigerian health sector performance. European Journal of Business and Management, 8(14), 8-14. 